\title{
Ekstrak Kulit dan Biji Anggur (Vitis vinifera) Menurunkan Jumlah Sel Neuron yang Rusak, Volume Infark, dan Memperbaiki Fungsi Motorik pada Tikus Wistar Model Stroke Iskemik
}

\author{
Astrid Nandikasari Lukito*, Mohammad Rasjad Indra**
}

\begin{abstract}
ABSTRAK
Stroke iskemik merupakan penyakit karena tersumbatnya pembuluh darah ke otak sehingga menyebabkan kerusakan neurologis. Kerusakan ini akibat perubahan seluler yang menyebabkan kerusakan neuron, edema otak, dan penurunan fungsi motorik. Ekstrak kulit dan biji anggur (Vitis vinifera) mengandung resveratrol yang mampu melintasi sawar darah otak dan memperbaiki kematian neuron melalui jalur patofisiologi seluler serta menginduksi ERK 1/2 pathway untuk regenerasi otak. Pada penelitian ini ingin diketahui korelasi antara perbaikan jumlah neuron yang rusak, volume infark, dan fungsi motorik setelah pemberian ekstrak kulit dan biji anggur pada tikus. Penelitian eksperimental ini menggunakan tikus (Rattus norvegicus) yang terbagi menjadi 5 kelompok yaitu (1) kontrol positif (+), (2) kontrol negatif (-), (3) dosis ekstrak $50 \mathrm{mg} / \mathrm{kgBB}$, (4) dosis ekstrak $100 \mathrm{mg} / \mathrm{kgBB}$, dan (5) dosis ekstrak $200 \mathrm{mg} / \mathrm{kgBB}$. Ekstrak diberikan selama 2 minggu. Tikus diinduksi stroke dengan metode unilateral carotid artery occlusion selama 45 menit. Kemudian diuji fungsi motoriknya dengan ladder rung walking test. Setelah 2 minggu, dianalisis fungsi motorik, jumlah neuron yang rusak dan volume infark dengan metode hematoksilin \& eosin. Berdasarkan uji Pearson terdapat korelasi yang cukup antara fungsi motorik dengan jumlah neuron yang rusak maupun volume infark (berturut-turut $R=$ $0,306 ; R=0,346)$. Sementara antara jumlah neuron yang rusak dengan volume infark terdapat korelasi yang kuat $(R=0,645, p=0,002 ; p<0,05)$. Kesimpulannya terdapat korelasi antara perbaikan jumlah sel neuron yang rusak, volume infark, dan fungsi motorik.
\end{abstract}

Kata kunci: Kulit dan biji anggur, Motorik, Infark, Regenerasi otak, Resveratrol, Stroke.

\section{Grape (Vitis vinifera) Peel and Seed Extract Decrease the Damaged Neurons, Infarc Volume, and Repair Motoric Function in Ischemic Stroke Rat Model}

\begin{abstract}
Ischemic stroke is a disease that caused by blockage of blood circulation in brain, then resulting in neurological failure. This is due to cellular changes that lead to damaged neurons, brain edema, and motoric function impairment. Grape (Vitis vinifera) peel and seed extract contain resveratrol which is able to pass through blood brain barrier and improve neuron death through cellular pathway and induce ERK $1 / 2$ pathway for brain regeneration. This study aim is to find the correlation between damaged neurons, infarct volume, and motoric function improvement after grape peel and seed extract treatment in rats. This experimental study used rats that were divided into 5 groups, (1) positive control, (2) negative control, (3) extract concentration $50 \mathrm{mg} / \mathrm{kgBB}$, (4) extract concentration $100 \mathrm{mg} / \mathrm{kgBW}$, and (5) extract concentration $200 \mathrm{mg} / \mathrm{kgBW}$. They were treated with grape peel and seed extract in 2 weeks. Inducing stroke performed with unilateral carotid artery occlusion for 45 minutes. Motoric function was assessed by ladder rung walking test. After 2 weeks, motoric function reassessment, damaged neurons and infarct volume were evaluated by hematoxylin \& eosin staining. Based on Pearson correlation test, there are moderate correlation between motoric function and the number of damaged neurons and infarct volume $(R=0.306$ and $R=0.346)$ respectively and strong correlation between damaged neurons and infarct volume $(R=0,645, p=0.002 ; p<0,05)$. In conclusion, there are correlation between the number of damaged neurons, infarct volume, and motoric function improvement.
\end{abstract}

Keywords: Grape peel and seed, Motoric, Infarc, Brain regeneration, Resveratrol, Stroke.

\footnotetext{
* Program Studi Pendidikan Dokter, FKUB

** Laboratorium Fisiologi, FKUB
} 


\section{PENDAHULUAN}

Stroke merupakan penyakit yang ditandai dengan hilangnya sirkulasi darah ke otak secara tiba-tiba dan mengakibatkan penurunan fungsi neurologis. ${ }^{1}$ Stroke di dunia, $87 \%$ nya disebabkan karena stroke iskemia. ${ }^{2}$ Prevalensi stroke di dunia adalah 30,7 juta. $^{3} \quad$ Setiap 4 menit, 1 orang meninggal dunia karena stroke. Di Indonesia penyakit stroke merupakan penyebab kematian nomor 1 yaitu sebesar $15,4 \%$ dari seluruh kematian. ${ }^{4}$

Stroke iskemik terjadi bila pembuluh darah yang memasok darah ke otak tersumbat oleh gumpalan darah sehingga sel-sel di daerah injury tidak menerima oksigen dan glukosa yang dibutuhkan. ${ }^{5}$ Otak merupakan organ yang sangat bergantung pada oksigen dan glukosa. ${ }^{6}$ Peristiwa ini menyebabkan mekanisme eksitotoksisitas yang dimulai dengan berkurangnya adenosine triphosphate (ATP) sehingga mengakibatkan $\mathrm{Na}^{+} / \mathrm{K}^{+}-$ATPase tidak dapat bekerja sehingga $\mathrm{Na}^{+}$yang juga bersamasama dengan air akan terperangkap di dalam sel dan $\mathrm{K}^{+}$tidak dapat keluar, akibatnya terjadi edema sitotoksik. $7,8 \mathrm{Hal}$ ini juga mengakibatkan peningkatan pelepasan glutamat yang menyebabkan meningkatnya $\mathrm{Ca}^{2+}$ dan kemudian meningkatkan kerusakan mitokondrial, membran sel, sitoskeleton, fragmentasi DNA, dan produksi radikal bebas sehingga pada akhirnya menyebabkan kematian sel neuron. ${ }^{7}$ Meningkatnya radikal bebas juga mengakibatkan kerusakan sel endotel sawar darah otak yang menyebabkan edema vasogenik. $^{9} \quad$ Kematian neuron mengakibatkan defisit fungsi neurologis primer. ${ }^{10}$ Penderita dapat mengalami kehilangan salah satu penglihatan, kesulitan berbicara, dan kelumpuhan ekstremitas, serta kesulitan dalam memori.

Neuron otak memiliki plastisitas yaitu kemampuan untuk beradaptasi seumurhidup terhadap perubahan, mengatasi cedera, dan mengkompensasi hilangnya fungsi dalam satu bagian otak dengan bekerja lebih keras di daerah lain. ${ }^{11}$ Kemampuan bertahan dan plastisitas yang dimiliki neuron diaktifkan melalui ERK (extracellular sinyal-regulated kinease) $1 / 2$ pathway. ERK 1/2 diaktifkan melalui growth factor seperti neurothropin, aktivitas neuronal, atau cAMP (cyclic adenosine monophosphate)..$^{12}$ Neutrophin, termasuk nerve growth factor (NGF) \& brainderived neutrophic factor (BDNF) juga melindungi neuron dari proses eksitotoksisitas. ${ }^{13}$

Rehabilitasi pasca stroke iskemik yang sudah ada saat ini memiliki 2 tujuan, yaitu meminimalkan cedera dan komplikasi yang terjadi. ${ }^{14}$ Obat utama yang digunakan antara lain antiplatelet, antikoagulan, dan trombolitik. ${ }^{15}$ Aspirin merupakan antiplatelet akan tetapi tidak dapat memperbaiki kerusakan yang disebabkan stroke. ${ }^{16}$ Tissue plasminogen activator (TPA) merupakan trombolitik yang digunakan untuk stroke akut dan mengembalikan sirkulasi darah ke otak, akan tetapi TPA menginduksi keluarnya toksin seperti glutamate sehingga mengakibatkan neurodegenerasi. ${ }^{17}$ Kedua obat ini tidak mampu memperbaiki kerusakan saraf yang sudah terjadi.

Resveratrol merupakan senyawa polifenol yang ditemukan pada red wine, anggur, dan kacang. Studi perkembangan mengindikasikan ekstrak resveratrol mengurangi insiden age-related neurological disorders termasuk degenerasi makular, stroke, dan demensia. ${ }^{18}$ Resveratrol mampu berfungsi sebagai neuroprotektif membantu menguptake glutamat, dan menurunkan radikal bebas. ${ }^{19,20}$ Resveratrol menginduksi pengeluaran neurotrophic factor seperti GDNF (glial cell line-derived neutrophic factor) dan BDNF yang berkontribusi untuk 
perkembangan dan kemampuan neuron untuk hidup. ${ }^{21}$

Kandungan resveratrol terbesar dapat ditemukan pada anggur (Vitis vinifera) terutama pada bagian kulit dan bijinya. Kandungan resveratrol dalam ekstrak kulit anggur kira-kira 24,06 $\mu \mathrm{g} / \mathrm{ml}$ dan pada ekstrak biji anggur $0,9850 \mu \mathrm{g} / \mathrm{ml} .^{22,23}$ Ekstrak biji anggur mampu melintasi sawar darah otak yang bersifat selektif permeabel. ${ }^{24}$ Selain resveratrol, anggur juga memiliki kandungan phenol lainnya seperti asam phenolat dan flavonoid (catechins, quercetin, dan antosianin). ${ }^{25,26}$ Anggur dapat tumbuh dengan baik di Indonesia terutama di daerah Jawa Timur (Probolinggo, Pasuruan, Situbondo), Bali, dan NTT (Kupang).

Karena salah satu kandungan anggur (Vitis vinifera) mengandung resveratrol yang dapat membantu uptake glutamat dan menurunkan radikal bebas sehingga dapat mengurangi kerusakan akibat eksitotoksisitas yang dapat berkontribusi dalam perbaikan jumlah sel neuron yang rusak, edema sel dan fungsi motorik, maka diperlukanlah suatu penelitian yang membuktikan korelasi antara perbaikan jumlah sel neuron yang rusak, volume infark akibat edema sel, dan fungsi motorik setelah pemberian ekstrak anggur dalam meningkatkan regenerasi neuron. Jadi, dengan mengetahui korelasi perbaikan yang dihasilkan, didapatkan suatu pengobatan alternatif terbaru berbasis pengobatan regeneratif serta dapat memaksimalkan efek regenerasi sel yang dihasilkan oleh ekstrak kulit dan biji anggur tersebut.

\section{BAHAN DAN METODE}

\section{Desain Penelitian}

Penelitian ini adalah penelitian eksperimental untuk mengetahui adanya korelasi antara perbaikan jumlah sel neuron otak yang rusak, volume infark, dan fungsi motorik pada tikus model stroke iskemik setelah pemberian ekstrak kulit dan biji anggur (Vitis vinifera) dalam meregenerasi sel saraf pusat. Desain penelitian ini menggunakan randomized pre test - post test controlled group design untuk menguji fungsi motorik dengan metode ladder rung walking test dan menggunakan post test only, control group design untuk mengukur perbaikan jumlah sel neuron yang rusak dan edema otak dengan metode pengecatan H\&E.

\section{Lokasi dan Waktu Penelitian}

Penelitian ini dilaksanakan di Laboratorium Farmakologi, Fisiologi, dan Patologi Anatomi Fakultas Kedokteran Universitas Brawijaya, Laboratorium Sentral IImu Hayati Universitas Brawijaya, dan Rumah Sakit Islam Aisiyah pada bulan Maret-April 2013.

\section{Sampel Penelitian}

Sampel penelitian ini terdiri dari 30 tikus percobaan yang diambil secara random sampling dan memenuhi kriteria yaitu tikus Rattus norvegicus Wistar jantan berumur 810 minggu, dengan berat badan rata-rata 150 gram, berwarna putih sehat, bertingkah laku normal, dan tidak ada kelainan anatomik, tikus memiliki nafsu makan yang baik selama penelitian, kondisi kesehatan yang stabil, dan hidup selama penelitian berlangsung.

\section{Persiapan Hewan Coba dan Pakan Hewan Coba}

Persiapan pemeliharaan hewan coba dimulai dengan persiapan alat dan bahan penelitian meliputi kandang, sekam, tempat makan dan minum, pakan tikus, alkohol 70 $\%$, tikus jantan galur wistar, dan dilakukan seleksi tikus berdasarkan usia, berat badan, jenis kelamin, dan kesehatan. Kelompok perlakuan dibagi menjadi 5 kelompk yaitu (1) kontrol negatif (-), (2) kontrol positif $(+),(3)$ ekstrak dosis $50 \mathrm{mg} / \mathrm{KgBB}$, (4) ekstrak dosis 
$100 \mathrm{mg} / \mathrm{KgBB}$, (5) ekstrak dosis 200 $\mathrm{mg} / \mathrm{KgBB}$. Diet yang digunakan dalam penelitian ini adalah pakan ayam/ParS (dengan kandungan air, protein, lemak, serat, abu, Ca, Phospor, antibiotika, coccidiostat) $66,6 \%$ dan tepung terigu 33,4 $\% .{ }^{27}$

\section{Pembuatan Ekstrak Kulit dan Biji Anggur}

Kulit dan biji anggur dikeringkan dengan sinar matahari dan kemudian digiling hingga lebih halus. Ekstraksi kulit dan biji anggur dilakukan dengan metode maserasi. Kulit dan biji anggur yang sudah digiling diletakkan di dalam labu erlenmeyer masingmasing sejumlah 100 gram. Maserasi dilakukan dengan merendam hasil penggilingan kulit dan biji anggur di dalam larutan yang terdiri dari $80 \%$ etanol dan 20 $\%$ air selama 72 jam. Larutan tersebut digunakan untuk melarutkan resveratrol. Setelah proses maserasi selesai, cairan yang berada di atas labu Erlenmeyer diletakkan di dalam alat yang bernama rotary evaporator hingga air tidak lagi menetes. Hasil ekstraksi tersebut dipanaskan kembali di dalam oven dengan suhu $60^{\circ} \mathrm{C}$ selama 15 menit.

\section{Studi Pendahuluan}

Studi pendahuluan bertujuan untuk membuktikan bahwa oklusi karotis interna dan eksterna yang dilakukan untuk penginduksian stroke berhasil mengakibatkan stroke iskemik pada tikus. Studi pendahuluan ini menggunakan 3 ekor tikus yang diinduksi dengan diikat pada arteri karotis interna dan eksterna selama 45 menit. Pada percobaan dengan ketiga tikus tersebut, tikus kedua dan ketiga terbukti mengalami stroke. Kemudian tikus dieutanasia, lalu jaringan otak diambil untuk dilakukan uji makroskopis. Tujuannya adalah untuk mengetahui adanya daerah iskemik pada jaringan otak, dengan menggunakan metode pewarnaan $\mathrm{H}$ \& E. Dari uji makroskopis jaringan otak tersebut, terbukti bahwa tikus kedua dan ketiga mengalami stroke iskemik.

\section{Aklimatisasi}

Seluruh kelompok tikus ditimbang berat badannya dan kemudian dilakukan randomisasi dalam pemilihan kelompok perlakuan agar setiap tikus memiliki kesempatan yang sama untuk mendapat perlakuan. Kemudian, tikus diaklimatisasi selama 12 hari. Selama aklimatisasi tikus diberikan minum dan pakan $30 \mathrm{~g} / \mathrm{hari}$ dengan komposisi 13,32 g PARS + 16,68 gr terigu $+10 \mathrm{ml}$ air. Penggantian sekam dilakukan 3 hari sekali. Di akhir aklimatisasi, berat badan tikus ditimbang kembali dan beratnya berkisar antara 150-200 gram.

\section{Induksi Stroke}

Metode induksi stroke dilakukan dengan metode unilateral carotid artery occlusion, yaitu dengan melakukan ligasi pada arteri karotis interna dan eksterna tikus pada sisi kiri. Sebelum prosedur, tikus dianestesi menggunakan ketamin dengan dosis 40 $\mathrm{mg} / \mathrm{kgBB}$. Kemudian tikus difiksasi dalam posisi supinasi di atas tempat pembedahan Selanjutnya bulu pada bagian leher dicukur lalu kulit bagian leher dibersinkan menggunakan alkohol $70 \%$, Setelah itu dilakukan insisi dengan skalpel pada garis tengah leher secara vertikal sepanjang 2-3 $\mathrm{cm}$. Setelah melokalisir arteri karotis interna dan eksterna, dilakukan ligasi selama 45 menit dengan menggunakan benang prolene ukuran 6.0. Setelah 45 menit, ikatan benang prolene dilepas. Lalu luka insisi tersebut ditutup dan dijahit dengan menggunakan benang catgut dan diolesi dengan antiseptik, kemudian luka ditutup dengan kasa steril. Tikus lalu disonde dengan dextrose $10 \%$. Pada hari berikutnya darah tikus diambil melalui ekor untuk dicek kadar marker MMP9 yang bertujuan untuk membuktikan tikus tersebut mengalami stroke. 


\section{Pemberian Ekstrak}

Pemberian ekstrak dilakukan dengan cara oral gavage selama 14 hari. Ekstrak kulit dan biji anggur dilarutkan dengan konsentrasi $1 \%$ Hal ini bertujuan untuk mempermudah penyerapan.

\section{Pengambilan sampel}

Sehari setelah hari terakhir pemberian sonde ekstrak kulit dan biji anggur, tikus dieutanasia dengan dimasukkan ke dalam tabung yang berisi eter. Setelah itu, dilakukan pembedahan untuk mengambil jaringan otaknya. Otak kemudian dimasukkan dalam larutan fiksasi, yaitu larutan PFA dengan konsentrasi $4 \%$.

\section{Penghitungan Jumlah Sel Neuron}

Pemotongan jaringan dilakukan secara koronal dimulai dari kiasma optikus menuju ke arah anterior. Jaringan otak dipotong dengan menggunakan mikrotom setebal 5 $\mu \mathrm{m}$. Pengecatan dilakukan dengan H\&E. Evaluasi dilakukan dengan menghitung jumlah sel neuron yang rusak. Neuron yang rusak ditandai dengan adanya perikarion yang mengkerut, nukleus piknosis, eosinopilic cytoplasm, dan vakuolisasi. Dalam melakukan pengamatan, digunakan mikroskop cahaya yang terintegrasi dengan kamera dengan pembesaran 400x. Setelah itu penghitungan dilakukan dengan menggunakan software countcell.

\section{Penghitungan Volume Infark}

Volume infark merupakan area yang rusak pada otak. Area infark ditandai dengan area yang berwarna merah muda pucat pada pewarnaan H\&E. Rumus yang digunakan $(\mathrm{L} 1+\mathrm{L} 21+\mathrm{L} 41+\mathrm{L} 61)^{*} 200 \mu \mathrm{m} . \mathrm{L}$ adalah luas area infark dan angka di belakang $\mathrm{L}$ menunjukkan potongan ke berapa. $L$ ditentukan menggunakan kamera Olympus XC 10 dan software dotslide microscope. Potongan pertama dihitung mulai dari kiasma optikus dan jarak antar potongan adalah $10 \mu \mathrm{m}$.

\section{Ladder Rung Walking Test}

Untuk menilai fungsi motorik tikus, digunakan uji ladder rung walking test. Pada uji ini, tikus berjalan pada besi berbentuk silinder yang disusun secara teratur dengan jarak tertentu sepanjang 1 meter. Kemudian diamati gerakan kaki kiri, kanan, dan jumlah langkah tikus. Apabila tikus terpeleset maka ini merupakan tanda-tanda kelemahan motorik tikus. ${ }^{28}$

\section{Analisis Data}

Data MMP9 diambil dari serum darah tikus 1 hari setelah penginduksian stroke iskemik, data skor fungsi motorik diambil setelah dilakukan induksi stroke iskemik dan setelah pemberian ekstrak biji dan kulit anggur selama 14 hari, sedangkan jaringan diambil setelah pemberian ekstrak biji dan kulit anggur selama 14 hari. Analisis yang dilakukan adalah uji korelasi Pearson. Jika $\mathrm{R}$ $\neq 0$ dapat dikatakan terdapat hubungan antar variabel. Uji Pearson digunakan juga untuk menilai kekuatan hubungan.

\section{HASIL}

Penelitian ini mengukur korelasi antara fungsi motorik, jumlah neuron yang rusak, dan volume infark. Data rata-rata selisih skor ladder rung walking test pasca stroke dan pasca sonde didapatkan pada kelompok 1 s/d 5 berturut-turut sebesar $0 ; 0,001 \pm 0,011$; $0,123 \pm 0,019 ; 0,064 \pm 0,024 ; 0,037 \pm$ 0,006 . Penghitungan jumlah neuron yang rusak didapatkan rata-rata jumlah neuron yang rusak dalam 10 lapangan pandang, pada kelompok $1-5$ berturut-turut sebesar $192.5 \pm 20.68 ; 111,1 \pm 44.43 ; 90 \pm 24,92$; dan $46,5 \pm 20,09$. Penghitungan volume infark didapatkan rata-rata pada kelompok 1 s/d 5 berturut-turut sebesar $63960149 \pm$ $26835017 \mu^{3} ; \quad 49533004 \pm 36458729$ $\mu \mathrm{m}^{3} ; 49512981 \pm 35055126 \mu \mathrm{m}^{3} ;$ dan $8782341 \pm 8743553 \mu \mathrm{m}^{3}$. 

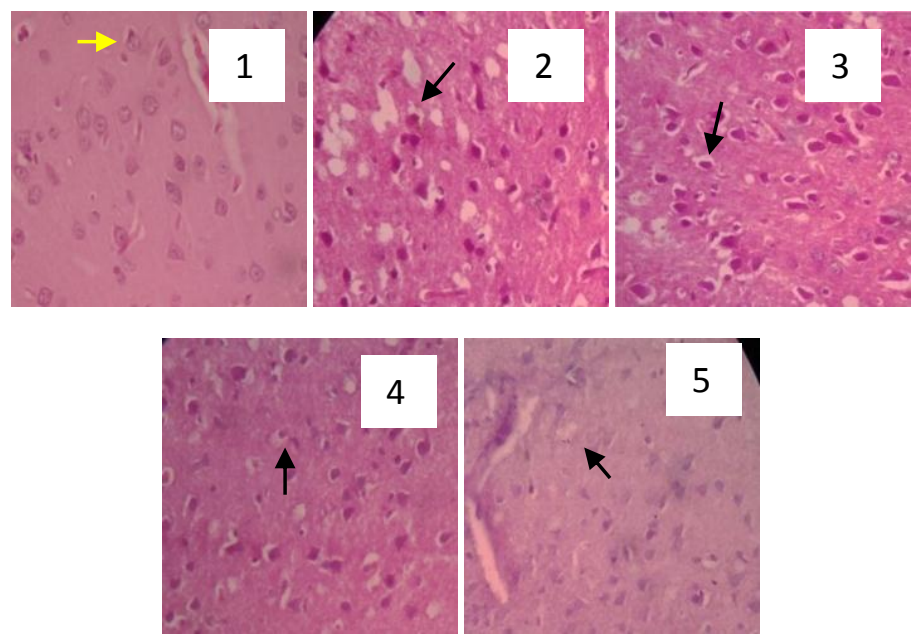

Gambar 1. Morfologi neuron antar kelompok perlakuan ekstrak kulit dan biji anggur setelah 2 minggu. Morfologi neuron yang normal (panah kuning) pada kelompok 1, sedangkan neuron yang rusak (panah hitam) terlihat pada kelompok 2-5.

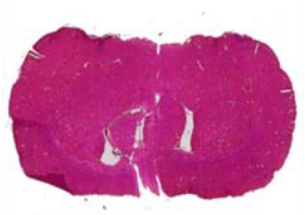

1

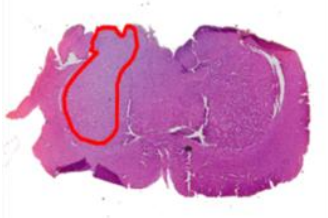

2

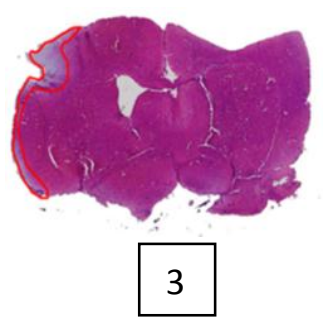

3

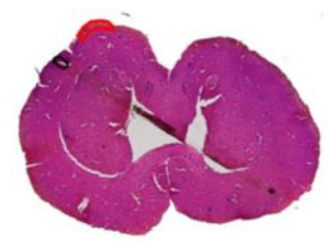

4

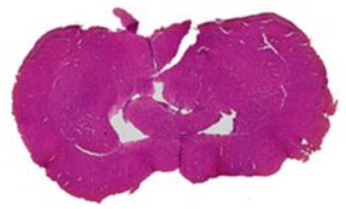

5

Gambar 2. Deteksi daerah infark pada otak tikus setelah pemberian ekstrak kulit dan biji anggur pada kelompok 3-5 dibandingkan kelompok 1 (kontrol negatif) dan kelompok 2 (kontrol positif). Garis merah menunjukkan daerah infark yang terjadi akibar edema sel.

Selanjutnya dilakukan uji korelasi Pearson. Hasil korelasi ditampilkan pada

Tabel 1. Pada uji normalitas didapatkan nilai $p>0,05$ yang berarti Ho diterima dan sebarannya mengikuti distribusi normal. 
Tabel 1. hasil uji korelasi Pearson

\begin{tabular}{|c|c|c|c|c|}
\hline \multicolumn{5}{|c|}{ Korelasi } \\
\hline & & Ladder_rung & Kerusakan_neuron & Volume_infark \\
\hline \multirow[t]{4}{*}{ Ladder_rung } & Pearson & 1 & ,306 & 346 \\
\hline & Correlation & & & \\
\hline & Sig. (2-tailed) & & 189 & 136 \\
\hline & $\mathrm{N}$ & 20 & 20 & 20 \\
\hline \multirow[t]{4}{*}{ Kerusakan_neuron } & Pearson & ,306 & 1 & $645^{*}$ \\
\hline & Correlation & & & \\
\hline & Sig. (2-tailed) & 189 & & ,002 \\
\hline & $\mathrm{N}$ & 20 & 20 & 20 \\
\hline \multirow[t]{4}{*}{ Volume_infark } & Pearson & ,346 & $645^{*}$ & 1 \\
\hline & Correlation & & & \\
\hline & Sig. (2-tailed) & , 136 & ,002 & \\
\hline & $\mathrm{N}$ & 20 & 20 & 20 \\
\hline
\end{tabular}

Keterangan: * menunjukkan korelasi yang signifikan pada hasil 0.05 (2-tailed)

\section{PEMBAHASAN}

Berdasarkan uji korelasi Pearson didapatkan semua variabel menunjukan hasil $\mathrm{R}>0$ yang berarti ada hubungan antara selisih skor ladder rung walking test, jumlah sel neuron yang rusak dan volume infark. Dari uji ini didapatkan korelasi antara selisih skor ladder rung walking test dengan jumlah neuron yang rusak sebesar 0,306 yang berarti korelasi yang cukup kuat. Hal ini menunjukkan bahwa kerusakan neuron terutama yang terjadi pada daerah girus presentralis area frontal otak (korteks motorik) menyebabkan penurunan fungsi motorik yaitu melemahnya ekstremitas kontralateral. ${ }^{29}$ Sehingga perbaikan pada jumlah sel neuron yang rusak juga akan memperbaiki fungsi motorik.

Selisih skor ladder rung walking test dan volume infark menunjukan korelasi sebesar 0,346 yang berarti korelasi yang cukup. Hal ini berarti adanya volume infark terjadi akibat edema sel neuron otak. ${ }^{30}$ Fungsi motorik tubuh dapat bekerja dengan baik apabila neuron sebagai penyalur impuls juga berfungsi normal. ${ }^{31}$ Adanya gangguan berupa edema memungkinkan fungsi motorik juga terganggu. Dengan demikian, pemberian ekstrak kulit dan biji anggur dapat memperbaiki edema otak juga memperbaiki fungsi motorik.
Adanya peningkatan volume infark dan penurunan fungsi motorik memiliki penyebab yang sama yaitu ROS. ${ }^{22,33}$ ROS yang terakumulasi ini mengakibatkan kerusakan permeabilitas endotel sehingga meningkatkan edema vasogenik, ROS juga menyebabkan kerusakan neuron yang menurunkan fungsi motorik. Resveratrol sebagai antioksidan bersama-sama menyebabkan perbaikan pada edema sehingga terjadi pengurangan volume infark dan perbaikan fungsi motorik. ${ }^{32}$

Sementara itu, antara jumlah neuron yang rusak dan volume infark menunjukkan korelasi kuat $(0,645)$ dengan signifikansi $p=$ $0,002(p<0,05)$. Hal ini disebabkan karena peningkatan permeabilitas sawar darah otak yang bermanifestasi dengan peningkatan volume infark dapat mengakibatkan kerusakan sel neuron sehingga dengan pemberian ekstrak kulit dan biji anggur yang mampu memperbaiki permeabilitas sawar darah otak juga mampu memperbaiki sel neuron yang rusak. Pada proses terjadinya kerusakan neuron dan edema juga memiliki jalur mekanisme yang sama yaitu eksitotoksisitas. Efek dari eksitotoksisitas ini mengakibatkan akumulasi air yaitu edema sitotoksisitas, dan juga mengakibatkan peningkatan ekspresi $\mathrm{NMDA}, \mathrm{Ca}^{2+}$, yang kemudian terjadi apoptosis dan kerusakan 
neuron. ${ }^{34}$ Terganggunya stabilitas sel neuron yang terjadi pada kedua parameter ini menampakkan adanya korelasi yang kuat antara kedua parameter ini. Resveratrol memiliki fungsi dalam memperbaiki keadaan eksitotosisitas. ${ }^{35}$ Adanya fungsi perbaikan ini menunjukkan hubungan yang kuat pada penurunan jumlah neuron yang rusak yang akan menyebabkan penurunan volume infark.

Pada penelitian terdahulu belum ada informasi tentang efek ekstrak kulit dan biji anggur yang memiliki kandungan resveratrol terhadap kekuatan korelasi antara jumlah sel neuron yang rusak, volume infark, dan perbaikan fungsi motorik. Namun juga ada penelitian yang mengungkapkan efek resveratrol terhadap jumlah sel neuron yang rusak, volume infark, atau fungsi motorik. Seperti pada penelitian pada tikus yang mengalami traumatic brain injury yang diberi resveratrol murni $100 \mathrm{mg} / \mathrm{kgBB}$ mampu menurunkan keparahan pada gangguan fungsi motorik dan kognitif serta menurunkan volume kontusio, akan tetapi tidak dinilai pula korelasi antara perbaikan fungsi tadi dengan menurunnya volume kontusio otak. ${ }^{36}$

Penelitian ini menunjukkan bahwa pemberian ekstrak kulit dan biji anggur (Vitis vinifera) yang mengandung resveratrol mampu menurunkan jumlah sel neuron yang rusak, menurunkan volume infark, dan memperbaiki fungsi motorik serta terdapat korelasi antara ketiga parameter tersebut, dengan korelasi yang paling kuat terdapat pada hubungan antara jumlah neuron yang rusak dan volume infark.

\section{KESIMPULAN}

Pemberian ekstrak kulit dan biji anggur (Vitis vinifera) dapat meregenerasi sel saraf pusat. Terdapat korelasi yang cukup antara perbaikan fungsi motorik dengan perbaikan jumlah sel neuron otak yang rusak dan perbaikan fungsi motorik dengan volume infark, dan ada korelasi yang kuat antara perbaikan jumlah sel neuron otak yang rusak dengan volume infark pada tikus model stroke iskemik.

\section{DAFTAR PUSTAKA}

1. Cruz-Flores $S$, Rabinstein A, Biller J, Elkind MS, Griffith P, Gorelick $P B$, Howard G, Leira EC, Morgenstern LB, Ovbiagele B, Peterson E, Rosamond W, Trimble B, Valderrama AL. Racial-Ethnic Disparities in Stroke Care: the American Experience: a Statement for Healthcare Professionals from the American Heart Association. American Stroke Association.Stroke. 2006; 42(7):2091-116.

2. Roger VL et al. Heart Disease and Stroke Statistics-2012 Update: a Report from the American Heart Association. Circulation. 2012; 125(1):e2-220.

3. (WHO) World Health Organization. The International Agenda for Stroke. Stroke AHAI ASA. Norrving B. 1st Global Conferences on Healthy Lifestyles and Noncommunicable Diseases Control. USW: University of Massachussets. 2011.

4. Riset Kesehatan Dasar. Jakarta: Badan penelitian dan Pengembangan Kesehatan, Departemen Kesehatan, Republik Indonesia. 2007.

5. Zieve D. Stroke. Los Angeles: National Library of Medicine. 2011.

6. Mergenthaler $P$, Dirnagl $U$, and Meisel A. Pathophysiology of Stroke: Lessons from Animal Models. Metabolic Brain Disease. 2004; 19 (3-4): 151-167.

7. Breton RR and Rodriguez CG. Excitotoxicity and Oxidative Stress in Acute Ischemic Stroke. Intech, Croatia. 2012. p29-58.

8. Liang D, Bhatta S, Gerzanich V, Simard JM. Cytotoxic Edema: Mechanism of Pathological Cell Swelling. Neurosurg Focus. 2007; 22(5): E2. 
9. Rosenberg GA. Molecular Physiology and Metabolism of The Nervous System. New York: Oxford University Press. 2012. p158.

10. Soyuer F. Ischemic Stroke: Motor Impairment and Disability with Relation to Age and Lesion Location. The Internet Journal of Neurology. 2005; 3(2): DOI: 10.5580/9b4.

11. Caplan A. Adult Mesenchymal Stem Cells for Tissue Engineering Versus Regenerative Medicine. J Cell Physiol. 2007; 213(2):341-347.

12. Cavanaugh $\mathrm{J}$ et al. Differential Regulation of Mitogen-Activated Protein Kinases ERK1/2 and ERK5 by Neurotrophins, Neuronal Activity, and cAMP in Neurons. The Journal of Neuroscience. 2008.

13. Nguyen TL et al. Neuroprotection Signaling Pathway of Nerve Growth Factor and Brain-Derived Neurotrophic Factor against Staurosporine Induced Apoptosis In Hippocampal H19-7/IGFIR. Korea: Department of Molecular Cell Biology, Samsung Biomedical Research Institute, Sungkyunkwan University School of Medicine. 2010.

14. Flaster M. How to Minimize Damage from Stroke. (Online). 2012. http://scienceparis.over-blog.com/article how-to-minimize-damage-from-strokesloyola-murray-flasterischaemicorthopnea-statin105224810.html. Diakses 13 Oktober 2012.

15. Mayo Clinic. Stroke: Treatment and Drug. (Online). 2012. http://mayoclinic.com/health/stroke/DS0 0150/DSECTION=treatments-anddrugs. Diakses 13 Oktober 2012.

16. Hennekens $\mathrm{CH}$ and Dyken ML. Aspirin as a Therapeutic Agent in Cardiovascular Disease. Circulation. 1997; 96:2751-2753.
17. Wang YF, Tsirka SE, Strickland S, Stieg PE, Soriano SG, Lipton SA. Tissue Plasminogen Activator (tPA) Increases Neuronal Damage after Focal Cerebral Ischemia in Wild-Type and tPA-Deficient Mice. Nat Med. 1998; 4:228-231.

18. Bastianetto $S$ and Quirion R. Resveratrol and Red Wine Constituents: Evaluation of Their Neuroprotective properties. Pharm News. 2001; 8:33-38.

19. de Almeida LMV, Celintano Piñeiro $C$, ConcliLeite M, Giovana B, Tramontina F, Feoli AM, Gottfried C, Gonçalves CA. Resveratrol Increases Glutamate Uptake, Glutathione Content, and S100B Secretion in Cortical Astrocyte Cultures. (Abstract). Cellular and Molecular Neurobiology. 2007; 27(5):661-668.

20. Simao $F$, Matté A, Matté $C$, Soares FM, Wyse AT, Netto CA, Salbego CG et al. Resveratrol Prevents Oxidative Stress and Inhibition of $\mathrm{Na}(+) \mathrm{K}(+)-$ ATPase Activity Induced by Transient Global Cerebral Ischemia in Rats. (Abstract). J Nutr Biochem. 2011; 22(10):921-8.

21. Zhang $\mathrm{F}$ et al. Resveratrol Promotes Neurotrophic Factor Release from Astroglia. China: Department of Pharmacology and Key Lab of Basic Pharmacology of Guizhou, Zunyi Medical College. 2012.

22. Pe'rez AIR, Ravento's RML, Lacueva CA, Boronat MCT. Method for the Quantitative Extraction of Resveratrol and Piceid Isomers in Grape Berry Skins. Effect of Powdery Mildew on the Stilbene Content. J Agric Food Chem. 2001; 49: 210-215.

23. Xiang $Y$, Zhang $T$, Zhang $X, M a ~ L$. Quantitative Analysis of Resveratrol from Grape Seeds and Grape Skins by High Performance Liquid 
Chromatography Method. PubMed. 2003; 32(5):490-2.

24. Jalil EC et al. Resveratrol Potently Reduces Prostaglandin $E_{2}$ Production and Free Radical Formation in Lipopolysaccharide-Activated Primary Rat Microglia. Journal of Neuroinflammation. $\quad 2007 ; \quad 4: 25$. DOI:10.1186/1742-2094-4-25.

25. Bunea $\mathrm{Cl}$, Nastasia POP, Babes Hodor AML, Ciobanu F, Bunea A et al. Qualitative and Quantitative Analysis of Phenolic Acids using High Performance Liquid Chromatography (HPLC) from Organic and Conventional Grapes. Bulletin UASVM Horticulture. 2012; 69(1).

26. Geros H, Chaves M, Delrot S. The Biochemistry of the Grape Berry. US: Bentham eBooks. 2012. p 180.

27. Murwani S, Mulyohadi A, dan Ketut M. Diet Aterogenik pada Tikus Putih (Rattus novergicus) strain Wistar sebagai Model Hewan Aterosklerosis. Indonesia Scientific Journal Database. 2006; 22(1): 6-9.

28. Schaar KL, Brenneman MM, Savitz SI. Functional Assessments in the Rodent Stroke Model. Experimental \& Transitional Stroke Medicine. 2010; 2:13.

29. Liu C, Shi Z, Fan L, Zhang C, Wang K, Wang B. Resveratrol Improves Neuron Protection and Functional Recovery in Rat Model of Spinal Cord Injury. (Abstract). Brain Res. 2011; 16(1374):100-9.

30. Lin TN, He YY, Wu G, Khan M, Hsu CY. Effect of Brain Edema on Infarct Volume in a Focal Cerebral Ischemia Model in Rats. American Heart Association. 1993; 24(1):117-121.

31. Chamorro A, Marshall RS, Sole JV, Tolosa E, Mohr JP. Motor Behavior in Stroke Patients with Isolated Medial
Frontal Ischemic Infarction. American Heart Association. 1997; 28:1755-1760.

32. Rosenberg GA. Molecular Physiology and Metabolism of the Nervous System. New York: Oxford University Press. 2012. p 158.

33. Ng JMJ, Chen MJ, Leung JYK, Peng ZF, Manikandan J, Qi RZ, Chuah MI, West AK, Vickers JC, Lu J, Cheung NM, Chung RS. Transcriptional Insights on the Regenerative Mechanics of Axotomized Neurons in Vitro. Journal of Cellular and Molecullar Medicine. 2012; 16:789-811.

34. Yenari MA and Han HS. Neuroprotective Mechanism of Hypothermia in Brain Ischemia. Nature Reviews Neuroscience. 2012; 13:267-278.

35. Tsai RY. Resveratrol Regulates NMethyl-D-Aspartate Receptor Expression and Suppresses Neuroinflammation in Morphine-Tolerant Rats. (Abstract). Anesth Analg. 2012; 115(4):944-52.

36. Singleton RH, Hong QY, C Edward Dixon. Resveratrol Attenuates Behavioral Impairments and Reduces Cortical and Hippocampal Loss in a Rat Controlled Cortical Impact Model of Traumatic Brain Injury. Journal of Neurotrauma. 2010; 27(6):1091-1099. 